\title{
OVER DE INHOUD VAN HET AMERIKAANSE BEGRIP „GENERALLY ACCEPTED ACCOUNTING PRINCIPLES”
}

\author{
door Drs. K. Kruisbrink
}

Sedert 1934 wordt in de Amerikaanse accountantsverklaringen een verwijzing opgenomen naar „generally accepted accounting principles”, een verwijzing die in belangrijke mate parallel loopt met de regeling in artikel 16 van het Reglement van Arbeid van het Nederlands Instituut van Accountants, waarin is bepaald, dat de goedkeurende accountantsverklaring met betrekking tot de jaarrekening inhoudt, dat deze is opgemaakt volgens goed koopmansgebruik.

De introductie van het begrip ,generally accepted accounting principles" beoogde een inperking van de vrijheid, die de ondernemingen zich konden veroorloven bij de samenstelling van de jaarrekening. De grens tussen wat wel en niet algemeen aanvaard was, bleek echter vanaf de aanvang onvoldoende duidelijk bepaald, tot zorg van de accountants die er naar dienden te verwijzen.

In de loop der jaren werden vanwege het Amerikaanse Instituut van Accountants verschillende pogingen gedaan om te komen tot een vastlegging van de „accounting principles”. Een belangwekkend historisch overzicht wordt hiervan gegeven in een onlangs verschenen brochure "The search for accounting principles", van de hand van Reed K. Storey, sinds 1 september 1964 directeur van het "accounting research"-bureau van het Amerikaanse Instituut van Accountants.

Zo werden in de periode 1939-1959 door de commissie „On accounting procedure" in totaal 51 accounting research bulletins uitgegeven, alle onderwerpen behandelende op het gebied van de ,accounting principles”.

Hoewel langs deze weg het begrip ,generally accepted accounting principles” nader inhoud werd gegeven, voelde men zich in Amerikaanse accountantskringen nochtans met deze gang van zaken niet gelukkig. Men realiseerde zich namelijk, dat door deze „bulletins" slechts een samenstel van aan de praktijk ontleende ervaringsregels was opgebouwd, zonder gemeenschappelijke grondslag en dientengevolge zonder veel innerlijke samenhang.

Een en ander leidde tot twijfel aan de deugdelijkheid van het richtsnoer van het goede koopmansgebruik en daarmede tevens aan de financiële verslaggeving van de ondernemingen.

In 1957 deed de toenmalige voorzitter van het Amerikaanse Instituut het voorstel tot een nieuwe wetenschappelijke benadering van het vraagstuk van de accounting principles.

Dit voorstel leidde - via een rapport van een speciale commissie „on research program" - tot de instelling in 1958 van de „Accounting Principles Board", die zich ten doel stelde: het wetenschappelijk onderzoek naar de ,generally accepted accounting principles". De uitvoering van dit onderzoek werd opgedragen aan een „Accounting research"-bureau.

Laatstgenoemde instantie is inmiddels al enkele jaren werkzaam en deed een zestal research-studies het licht zien.

De keuze van de door ,accounting research" te bestuderen onderwerpen wordt steeds in overleg met de Accounting Principles Board (A.P.B.) gemaakt. Bij de 
uitvoering van het onderzoek wordt Accounting research geadviseerd door een „Project advisory committe" samengesteld uit specifieke deskundigen ten aanzien van het in studie genomen onderwerp.

Het research-bureau werkt met een eigen staf van deskundigen en rapporteert haar bevindingen in het openbaar, tenzij de meerderheid van het Project advisory committee zich tegen de publikatie verzet.

De publikaties van Accounting research zijn niet te beschouwen als officiële uitspraken vanwege het Amerikaanse instituut; zij dienen uitsluitend om de discussie en belangstelling van de vakgenoren te stimuleren. Wel worden deze publikaties zorgvuldig door de A.P.B. bestudeerd en na een uitvoerig onderzoek, waaraan een enquête onder ca. 3.000 belanghebbenden te pas zal kunnen komen, zal de A.P.B. tot een eigen oordeel kunnen komen. Daarbij kunnen de conclusies of aanbevelingen van het research-bureau geheel of ten dele worden overgenomen of wel worden afgewezen.

Deze nieuwe aanpak van het vraagstuk ,accounting principles” onderscheidt zich van vorige in een drietal opzichten.

Allereerst wat betreft de methodologische opzet: thans wordt de deductieve methode vooropgesteld. Het gehele bouwwerk van de theorie (van de generally accepted accounting principles) zal moeten worden opgebouwd vanuit een enkel samenstel van premissen.

Een tweede kenmerk is, wat men zou kunnen noemen de „openbaarheid van overwegingen”. In de tot 1959 gepubliceerde accounting research bulletins werden conclusies en aanbevelingen opgenomen, zonder uitvoerige toelichting van de overwegingen en argumenten die tot de conclusies hadden geleid. De thans gepubliceerde research-studies bevatten een volledig exposé van de overwegingen en beredeneringen.

Als derde kenmerk valt te noemen de poging tot synthese tussen de theoretische benadering van het research-bureau en opvattingen van de praktiserende accountants, die zitting hebben in de A.P.B.

In verband met de plannen van het Nederlands Instituut van Accountants met betrekking tot de instelling van een wetenschappelijk bureau, leek het zinvol iets nader in te gaan op de organisatie van de wetenschappelijke arbeid van het Amerikaanse Instituut van Accountants.

Zoals opgemerkt, zijn in Amerika reeds een zestal research-studies gepubliceerd, t.w.

No. 1. The basic postulates of accounting.

"2. "Cash flow" analysis and the funds statement.

3. A tentative set of broad accounting principles for business enterprises.

4. Reporting of leases in financial statements.

5. A critical study of accounting for business combinations.

6. Reporting the financial effects of price-level changes.

Van bovengenoemde publikaties waren de eerste en de derde, respectievelijk betreffende de ,basic postulates" en ,a tentative set of broad accounting principles", studies die pasten in de opzet van een zuiver wetenschappelijke benadering van het vraagstuk van de ,accounting principles”. 
Hoewel deze studies van onmiskenbare waarde werden geacht, oordeelde de Accounting Principles Board het bij nader inzien toch gewenst meer aandacht te gaan schenken aan specifieke onderwerpen van meer praktisch belang. Deze heroriëntatie leidde tot research-studies, zoals die over de verslaggeving in geval van leasing-contracten (no. 4).

De genoemde research-studies hebben nog slechts in een enkel geval officiële uitspraken („opinions”) van de Accounting Principles Board tot gevolg gehad. Sedert de oprichting publiceerde de A.P.B. vijfmaal een „opinion”; hiervan had de laatste (no. 5) van september 1964 betrekking op een onderwerp, dat door het research-bureau was bestudeerd t.w. de verslaggeving in geval van leasing contracten. De andere vier hielden géén verband met de genoemde research-studies.

De gepubliceerde „opinions” gaven echter reeds wel aanleiding tot een principiële discussie binnen het Amerikaanse Instituut van Accountants, naar de betekenis van een „opinion” voor de openbare accountant. De vraag was namelijk gerezen, of de leden van het Instituut er in hun verklaring bij de jaarrekening melding van zouden moeten maken, indien deze jaarrekening zou zijn opgemaakt volgens een methodiek, welke afwijkt van die welke door de A.P.B. (in één van haar ,opinions”) is geadviseerd.

Omtrent deze kwestie is inmiddels een beslissing gevallen. In een „special bulletin" van oktober 1964 getiteld: „Disclosure of departures from opinions of Accounting Principles Board" wordt de leden van het Amerikaanse instituut mededeling gedaan van het bestuursbesluit dat met ingang van het boekjaar aanvangende na 31 december 1965 nieuwe richtlijnen van kracht zullen zijn. Vanaf genoemde datum zal de accountant bij een jaarrekening die is samengesteld met toepassing van ,an accounting principle that differs materially in its effects from one accepted in an opinion of the A.P.B.", alleen een goedkeurende verklaring kunnen afgeven, indien hij van mening is dat het toegepaste beginsel nochtans „Substantial authorative support” bezit (d.w.z. goed koopmansgebruik is). De accountant zal van deze omstandigheid echter melding moeten maken in zijn rapport en tevens dienen aan te geven welke invloed de toepassing van het afwijkende beginsel op het jaarresultaat heeft gehad, m.a.w. hoe groot het jaarresultaat zou zijn geweest, als de jaarrekening geheel was samengesteld in overeenstemming met de aanbevelingen van de A.P.B.

De ,disclosure” mag ook geschieden door middel van een voetnoot bij de jaarrekening.

Met de „opinions” van de A.P.B. worden in dit verband gelijk gesteld de voorheen gepubliceerde "Accounting Research bulletins". In dit verband heeft de A.P.B. zich tot taak gesteld vóór 31 december 1965 te onderzoeken of er research bulletins zijn die voor herziening of eventueel intrekking in aanmerking komen.

Tenslotte maakt het Special bulletin er melding van, dat onderzocht zal worden in hoeverre de reglementen van het Amerikaanse instituut moeten worden aangevuld, aangezien thans niet is voorzien in gevallen van overtreding van deze nieuwe „recommendation”. 